\title{
Study of the mechanical behaviour of reclaimed asphalt aggregates without binder addition
}

\author{
Laura Gaillard ${ }^{1, *}$, Cyrille Chazallon ${ }^{1}$, Pierre Hornych ${ }^{2}$, and Juan Carlos Quezada ${ }^{1}$ \\ ${ }^{1}$ Université de Strasbourg, Laboratoire des sciences de l'ingénieur, de l'informatique et de l'imagerie, ICUBE, UMR 7357 , \\ CNRS, INSA de Strasbourg, 24 Boulevard de la Victoire 67084 Strasbourg Cedex, France \\ ${ }^{2}$ IFSTTAR, LAMES, Allée des Ponts et Chaussées - Route de Bouaye 44644 Bouguenais Cedex, France
}

\begin{abstract}
The objective of this paper is to investigate a source of reclaimed asphalt aggregates without binder addition. To this end, a series of triaxial tests was performed. First, monotonic triaxial tests allowed to determine failure resistance of the material at $20^{\circ} \mathrm{C}, 50^{\circ} \mathrm{C}$ and at $20^{\circ} \mathrm{C}$ with a prior preheating at $50^{\circ} \mathrm{C}$. Then, the resilient and permanent behaviours at $20^{\circ} \mathrm{C}$ were studied thanks to Repeated Load Triaxial (RLT) tests with different levels of loading. The results show that increasing the temperature test implies a drop of failure resistance but a higher cohesion. RLT tests reveal a stress dependent resilient behaviour. Finally, the experimental results were compared with calibrations of the non-linear elastic Boyce model.
\end{abstract}

\section{Introduction}

Asphalts aggregates (AA) are produced during the removal of asphalt pavements. From environmental perspectives, the reuse of AA progresses in either hot or cold recycling: a mix between binders, AA and sometimes virgin materials. The recycling is hot if all constituents in the mixture are heated; the process is cold if at least the aggregates are not heated. Several researches were carried out to develop the incorporation of AA in new asphalt mixtures [1-6], in foamed asphalts [7-9] or in bitumen emulsions [10-12]. This work studies the possibility of cold recycling without binder addition by means experimental and model methods commonly used for Unbound Granular Materials (UGM). The cold process is an important market because beyond $50 \mathrm{mg} / \mathrm{kg}$ of Polycyclic Aromatic Hydrocarbons (PAH) the hot recycling is prohibited in France. Consequently, reuse the AA with a PAH content between 50 and $500 \mathrm{mg} / \mathrm{kg}$, the allowable limits, reduces the waste of resources.

From the experimental point of view, monotonic triaxial tests allowed to study the effect of the temperature on the failure resistance. Then, in order to analyse the permanent and resilient behaviours of AA, Repeated Load Triaxial (RLT) tests were performed with different stress paths. Finally, calibrations of the Boyce model allowed to describe the resilient strains.

\section{Material and test programme}

\subsection{Material characterization}

The studied material is reclaimed Asphalt Aggregates (AA) of Strasbourg and its suburbs. AA arise from the demolition of wearing courses. Table 1 details the main properties of the material. Figure 1 displays the particle size distribution, as well as both grading ranges of French Standards: UGM 0/20 mm [13] and asphalt mixture 0/20 $\mathrm{mm}[14]$.

The grading curve was determined by wet method in accordance with French Standard XP P 94-041 [15], and Modified Proctor Test (NF P 94-093 [16]) allowed to obtain the optimum water content as well as the maximum dry density.

Overall, the particle size distribution of AA is included in both grading ranges. For coarse elements, the curve is near the upper limit of ranges and for fine elements, it exceeds UGM range. AA are a complex material between UGM and asphalt mixture.

Table 1. Characteristics of reclaimed Asphalt Aggregates.

\begin{tabular}{|c|c|}
\hline PAH content & $298 \mathrm{mg} / \mathrm{kg}$ \\
\hline Grading & $0 / 20 \mathrm{~mm}$ \\
\hline Optimum water content & $5.86 \%$ \\
\hline Maximum dry density & $2.02 \mathrm{~g} / \mathrm{cm}^{3}$ \\
\hline $\begin{array}{c}\text { Binder content } \\
\text { NF EN 12697-1 [17] }\end{array}$ & $4.36 \%$ \\
\hline $\begin{array}{c}\text { Needle penetrability } \\
\text { NF EN 1426 [18] }\end{array}$ & $13^{1 / 10} \mathrm{~mm}$ \\
\hline $\begin{array}{c}\text { Ring \& Ball } \\
\text { NF EN 1427 [19] }\end{array}$ & $69.4^{\circ} \mathrm{C}$ \\
\hline
\end{tabular}

\footnotetext{
* Corresponding author: laura.gaillard@insa-strasbourg.fr
} 


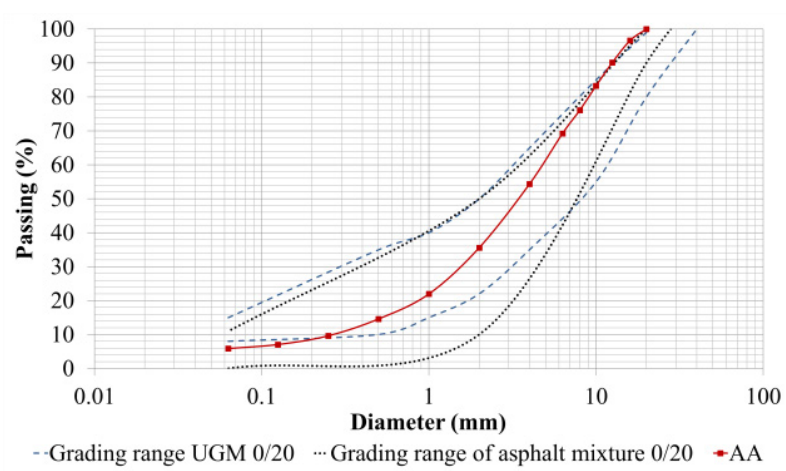

Fig. 1. Particle size distribution of Asphalt Aggregates.

\subsection{Sampling}

The process proposed in the Re-Road European project [20] was followed. After collecting materials from several spots of initial stockpile, the AA are stored in roof-shaped pile layer by layer (figure 2). Then, the material is taken in tranches in order to obtain homogeneous samples.

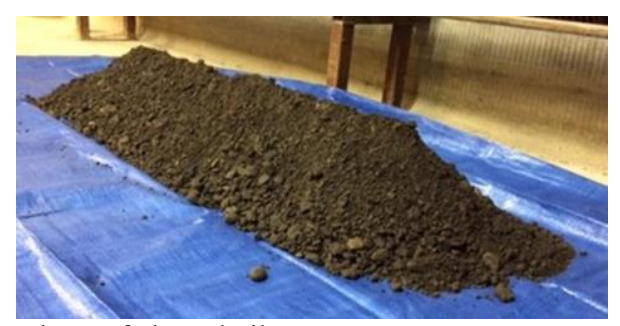

Fig. 2. The roof-shaped pile.

Based on the researches of Jing et al. [21] and Ho et al. [22], the sample production needs several steps:

- The material is dried in oven at $50^{\circ} \mathrm{C}$ during 72 hours.

- The AA and a quantity of water are mixed in heating mixer at the target temperature.

- The mix is sealed in airtight bag for 48 hours at least, at the target temperature.

- The specimens are compacted using the vibrating hammer method [23] in seven layers at $97 \%$ of maximum dry density, $1.96 \mathrm{~g} / \mathrm{cm}^{3}$, and at the required temperature.

All samples present the same characteristics summarised in table 2. The standard NF EN 13286-7 [24] prescribes sizes for specimen to represent the in-situ behaviour: a diameter at least five times higher than the largest particle $(20 \mathrm{~mm})$ and a height equal to twice the diameter.

Table 2. Characteristics of specimen.

\begin{tabular}{|c|c|c|c|}
\hline Diameter & Height & Void ratio & Porosity \\
\hline $150 \mathrm{~mm}$ & $300 \mathrm{~mm}$ & $27 \%$ & $21 \%$ \\
\hline
\end{tabular}

\subsection{Triaxial apparatus}

The apparatus used for the laboratory test is shown on figure 3 . The sample is placed in a temperature controlled triaxial cell filled with water and the loading is applied by a pneumatic system. An axial force transducer in the cell, a cell pressure transducer, four temperature sensors, an axial displacement transducer LVDT and three Hall Effect transducers ensure the measurement.
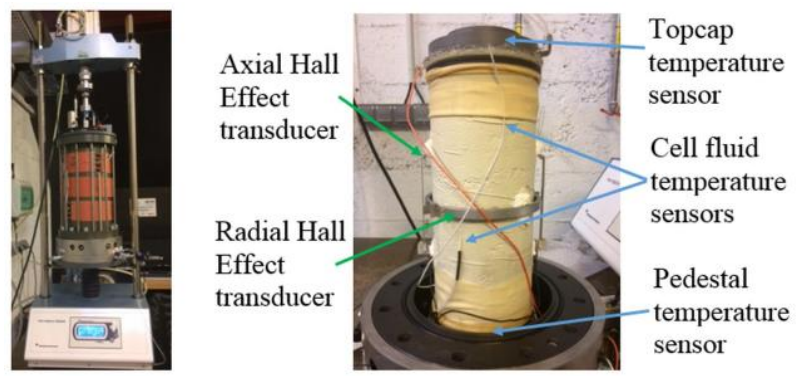

Fig. 3. Temperature controlled cell and instrumented specimen.

\subsection{Monotonic triaxial tests}

In addition of a constant confining pressure $\sigma_{3}$, the sample is submitted to a vertical stress q, named deviator stress, which increases until the failure. The test programme is composed of 12 experiments: four confining pressures at three temperatures. Table 3 displays the main characteristics of tests. Each sampling step is performed at the target temperature. For the test with preheating, the specimen is prepared and kept at $50^{\circ} \mathrm{C}$ during 8 hours in the cell, then it is cooled at $20^{\circ} \mathrm{C}$.

Table 3. Characteristics of monotonic triaxial tests.

\begin{tabular}{|c|c|c|c|}
\hline $\begin{array}{c}\text { Water } \\
\text { content }\end{array}$ & Velocity & Temperature & $\boldsymbol{\sigma}_{3}$ \\
\hline $3.9 \%$ & $\begin{array}{c}0.3 \\
\mathrm{~mm} / \mathrm{min}\end{array}$ & $\begin{array}{c}20^{\circ} \mathrm{C}-50^{\circ} \mathrm{C}- \\
20^{\circ} \mathrm{C} \text { with } \\
\text { preheating at } \\
50^{\circ} \mathrm{C}\end{array}$ & $\begin{array}{c}0 \mathrm{kPa}-20 \mathrm{kPa}- \\
40 \mathrm{kPa}-70 \mathrm{kPa}\end{array}$ \\
\hline
\end{tabular}

\subsection{Repeated Load Triaxial (RLT) tests}

RLT test is one of the most reliable tests to analyse the resilient and permanent behaviours of unbound granular materials. The French Standard NF EN 13286-7 [24] defines this test. The loadings are a Constant or Variable Confining Pressure $\sigma_{3}(\mathrm{CCP}$ or VCP) and a cyclic deviator stress q. First, the sample is subjected to a conditioning, namely a high stress level over 30000 cycles, to stabilise the permanent strains. Secondly, several stress paths are applied over 100 cycles in order to observe the resilient behaviour. All RLT tests were carried out at a water content of $3.9 \%$ and ambient temperature. The conditioning phase was studied at a frequency of $2 \mathrm{~Hz}$, and the resilient test at $0.1 \mathrm{~Hz}$. The maximum water content commonly used is the optimum water content minus $1 \%$ to avoid drainage. This phenomenon is important for hydrophobic materials such as AA. 


\section{Experimental results and analysis}

\subsection{Monotonic triaxial tests}

The rupture lines are characterised by the equation (1) which is a function of deviator stress $q$, mean stress $p$, parameter $\mathrm{m}$ and parameter $\mathrm{s}$. These elements are obtained by formulae (2) to (5).

$$
\begin{aligned}
& q=m \cdot p+s \\
& q=\sigma_{l}-\sigma_{3} \\
& p=\left(\sigma_{1}+2 \sigma_{3}\right) / 3 \\
& m=(6 \cdot \sin (\varphi)) /(3-\sin (\varphi)) \\
& s=(6 \cdot c \cdot \cos (\varphi)) /(3-\sin (\varphi))
\end{aligned}
$$

For each temperature, the Mohr-Coulomb parameters are calculated: cohesion $\mathrm{c}$ and friction angle $\varphi$ at peak stress. Table 4 gives the values of $\mathrm{m}, \mathrm{s}, \mathrm{c}$ and $\varphi$.

Table 4. Parameters of AA for the failure test.

\begin{tabular}{|c|c|c|c|}
\hline $\mathbf{m}$ & $\mathbf{5 0}^{\circ} \mathbf{C}$ & $\mathbf{2 0}^{\circ} \mathbf{C}$ & $\begin{array}{c}\text { Preheating } \\
\mathbf{5 0}^{\circ} \mathbf{C}-\mathbf{T e s t} \\
\mathbf{2 0}\end{array}$ \\
\hline $\mathbf{s} \mathbf{C}$
\end{tabular}

Some points can be stated for samples compacted at the same density:

- Higher temperature implies lower resistance at failure test. In fact, the mastic coating of the aggregate is sensitive at $50^{\circ} \mathrm{C}$ and consequently the Mohr-Coulomb parameters decrease.

- The preheating implies a higher cohesion.

\subsection{Repeated Load Triaxial (RLT) tests}

A positive axial strain $\varepsilon_{1}$ indicates a reduction of the sample height and a negative radial strain $\varepsilon_{3}$ an increase in the diameter. The volumetric and deviatoric strains are defined by the following relationship:

$$
\begin{aligned}
\varepsilon_{v} & =\varepsilon_{1}+2 \varepsilon_{3} \\
\varepsilon_{q} & =2\left(\varepsilon_{1}-\varepsilon_{3}\right) / 3
\end{aligned}
$$

\begin{tabular}{|c|c|c|c|c|c|}
\hline \multirow{2}{*}{$\begin{array}{l}\Delta q / \\
\Delta p\end{array}$} & \multirow{2}{*}{$\underset{(\mathrm{kPa})}{\Delta \mathrm{q}}$} & \multirow{2}{*}{$\underset{(\mathrm{kPa})}{\Delta \mathrm{p}}$} & \multicolumn{2}{|c|}{$\begin{array}{c}\text { Initial stress state } \\
(\mathrm{kPa})\end{array}$} & \multirow{2}{*}{$\begin{array}{c}\sigma_{3} \\
(\mathrm{kPa})\end{array}$} \\
\hline & & & $q_{0}$ & $\mathbf{p}_{0}$ & \\
\hline 3 & 340 & 113 & 3 & 71 & 70 \\
\hline
\end{tabular}

\subsubsection{Permanent strains}

The stress level, detailed in table 5, is applied to the sample over 30000 cycles at $2 \mathrm{~Hz}$.
Table 5. Cyclic stress paths for the conditioning.

Figures 4 and 5 show the evolution of axial and radial permanent strains. During the first cycles, there is a rapid increase of the strains, then the strains show a slower evolution. The ratio $\Delta \varepsilon / \Delta \mathrm{N}$ over the last hundred cycles is $2.4 * 10^{-7}$ for the axial strains and $-6.7 * 10^{-8}$ for radial strains.

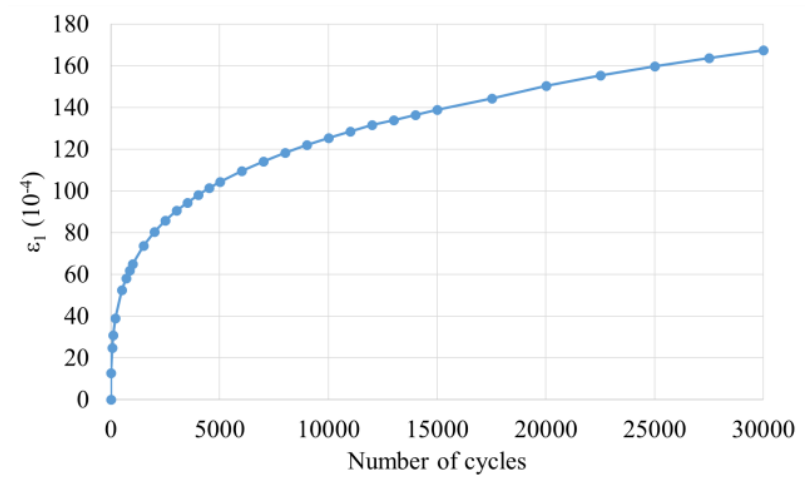

Fig. 4. Permanent axial strains.

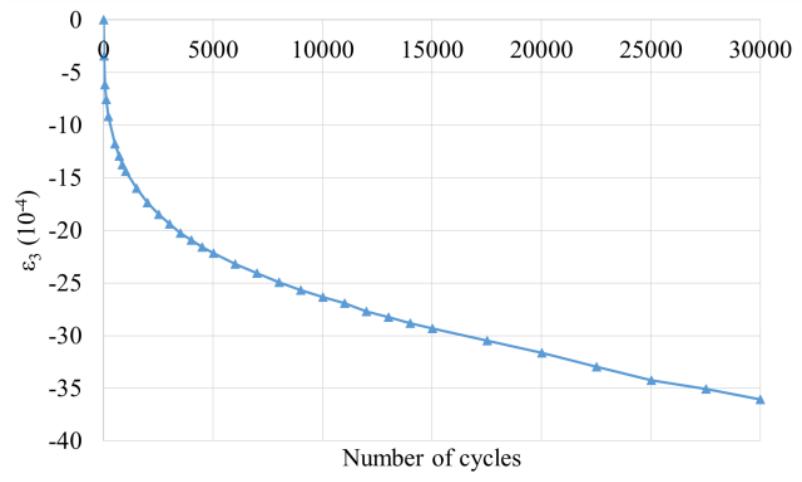

Fig. 5. Permanent radial strains.

\subsubsection{Resilient strains}

The resilient behaviour is studied at $0.1 \mathrm{~Hz}$ with ten stress paths. Figure 6 displays the stress paths of slope $\Delta q / \Delta p=$ 3 (CCP method) and figure 7 the stress paths of slopes equal to $0,0.5,1,1.5$ and 2 (VCP method).

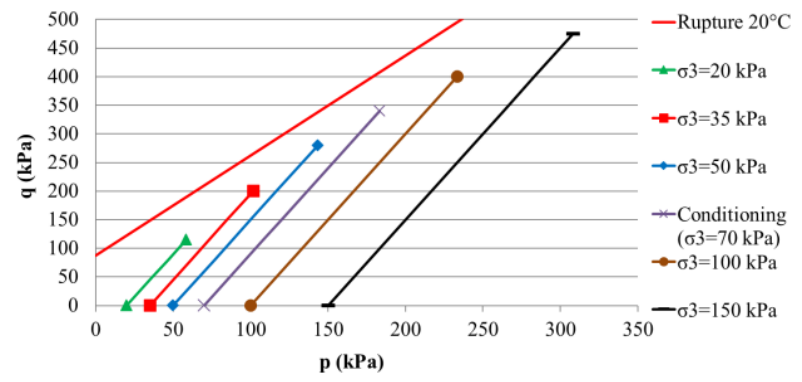

Fig. 6. Stress paths of slope equal to 3 . 


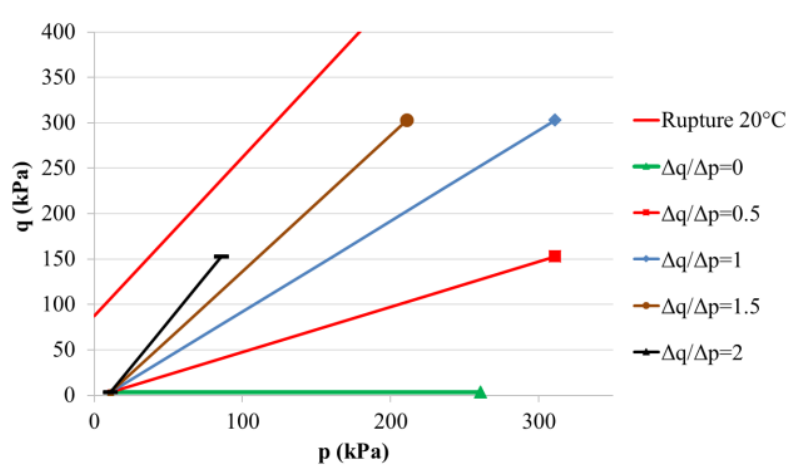

Fig. 7. Stress paths of slope equal to $0,0.5,1,1.5$ and 2 .

The non-linear elastic model proposed by Boyce [25] is widely used to describe the resilient behaviour of Unbound Granular Materials (UGM). This model was modified by Hornych et. al [26] to take into account the anisotropy of materials. The followed equations define mean stress $\mathrm{p}^{*}$, deviator stress $\mathrm{s}^{*}$, volumetric strain $\varepsilon_{v}$ and deviatoric strain $\varepsilon_{q}$ used in the Boyce model.

$$
\begin{aligned}
& p^{*}=\left(\gamma \sigma_{1}+2 \sigma_{3}\right) / 3 \\
& q^{*}=\gamma \sigma_{1}-\sigma_{3}, 0<\gamma<1 \\
& \varepsilon_{v}=\left(\mathrm{p}^{* \mathrm{n}} / \mathrm{p}_{\mathrm{a}}{ }^{\mathrm{n}-1}\right) \cdot\left[(\gamma+2) /\left(3 K_{a}\right)+(n-\right. \\
& \text { 1). } \left.(\gamma+2) \cdot\left(q^{*} / p^{*}\right)^{2} /\left(18 G_{a}\right)+(\gamma-1) \cdot q^{*} /\left(3 G_{a} \cdot p^{*}\right)\right] \\
& \varepsilon_{q}=(2 / 3) \cdot\left(\mathrm{p}^{* \mathrm{n}} / \mathrm{p}_{\mathrm{a}}{ }^{\mathrm{n}-1}\right) \cdot\left[(\gamma-1) /\left(3 K_{a}\right)+(n\right. \\
& \text {-1). } \left.(\gamma-1) \cdot\left(q^{*} / p^{*}\right)^{2} /\left(18 G_{a}\right)+(2 \gamma+1) \cdot q^{*} /\left(6 G_{a} \cdot p^{*}\right)\right]
\end{aligned}
$$

Bulk modulus $\mathrm{K}_{\mathrm{a}}$, shear modulus $\mathrm{G}_{\mathrm{a}}$, anisotropy coefficient $\gamma$ and $n$ are the model parameters, then $p_{a}$ is the atmospheric pressure $(100 \mathrm{kPa})$. The parameters are optimized by the least square method, in which the squared error is minimised $\mathrm{S}_{\min }$. This error and the correlation value $\mathrm{c}$ are determined by the relationship (12) and (13).

$$
\begin{gathered}
S_{\min }=\Sigma\left(\varepsilon_{v}-f\left(p^{*}, q^{*}\right)\right)^{2 / \Sigma\left(\varepsilon_{v}-m_{v}\right)^{2}+} \\
\Sigma\left(\varepsilon_{q}-g\left(p^{*}, q^{*}\right)\right)^{2} / \Sigma\left(\varepsilon_{q}-m_{q}\right)^{2} \\
c=1-\left(S_{\min } / 2\right)^{1 / 2}
\end{gathered}
$$

With $\mathrm{f}\left(\mathrm{p}^{*}, \mathrm{q}^{*}\right), \mathrm{g}\left(\mathrm{p}^{*}, \mathrm{q}^{*}\right)$ the Boyce model volumetric and deviatoric strains and $\mathrm{m}_{\mathrm{v}}, \mathrm{m}_{\mathrm{q}}$ the average values of volumetric and deviatoric experimental strains.

Figures 8 and 9 show respectively the resilient deviatoric strains $\varepsilon_{\mathrm{q}}$ and the resilient volumetric strains $\varepsilon_{\mathrm{V}}$ for the stress paths of slope 3 . Figures 10 and 11 detail the same strains for the stress paths of slopes 0 to 2 . Two calibrations with Boyce model were fitted: one with the six stress paths of slope 3 (named fit A) and the other with the stress paths of slopes $0,0.5,1,1.5$ and 2 (named fit B). The model parameters and the correlation value are summarised in table 6 .

The following points can be listed:

- For $\Delta \mathrm{q} / \Delta \mathrm{p}=3$ on figure 8 , at lower confining pressures the yield curve is steeper than at higher confining pressures. Regarding the other ratios $\Delta \mathrm{q} / \Delta \mathrm{p}$, the lower the slope the deviatoric strains decrease and next are negative. - All the volumetric strains are positive, indicating a contraction. Moreover, the slopes of 3 present strains far lower than the other slopes. The reason for this is that the radial strains for $\Delta \mathrm{q} / \Delta \mathrm{p}=3$ are low and negative whereas for the other slopes $\varepsilon_{3}$ are high and positive.

- Fit B reveals moduli values more important than fit A. The bulk modulus $K_{a}$ of fit $B$ is five times higher than $K_{a}$ of fit $A$, and the shear modulus $G_{a}$ of fit $B$ is more than double $G_{a}$ of fit $A$.

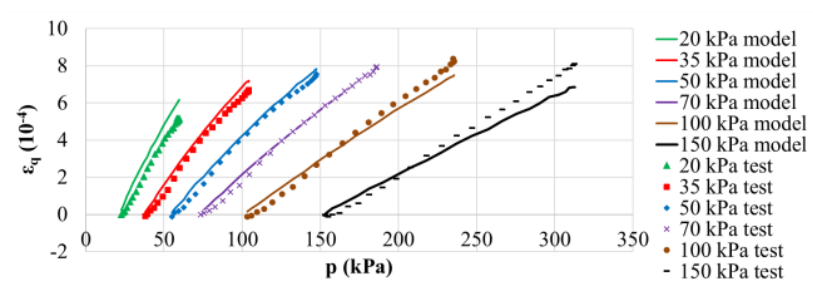

Fig. 8. Resilient deviatoric strains $\Delta \mathrm{q} / \Delta \mathrm{p}=3$.

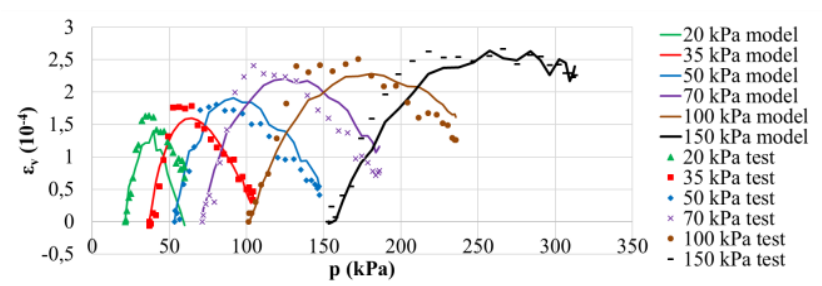

Fig. 9. Resilient volumetric strains $\Delta \mathrm{q} / \Delta \mathrm{p}=3$.

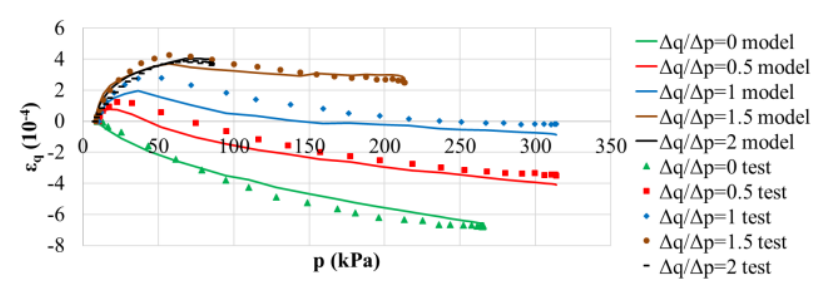

Fig. 10. Resilient deviatoric strains $\Delta \mathrm{q} / \Delta \mathrm{p}=0,0.5,1,1.5$ and 2 .

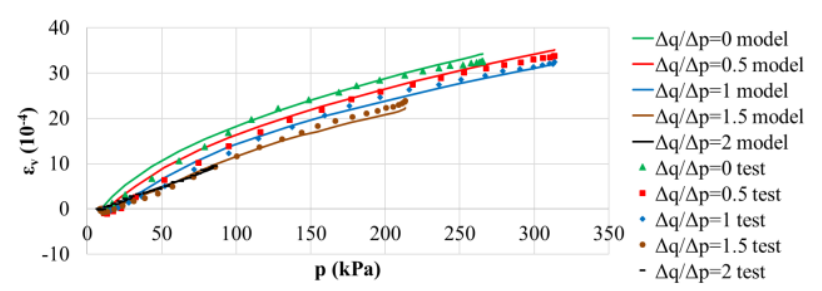

Fig. 11. Resilient volumetric strains $\Delta q / \Delta p=0,0.5,1,1.5$ and 2 .

Table 6. Mohr-Coulomb parameters.

\begin{tabular}{|c|c|c|c|c|c|c|}
\hline fit & $\mathbf{\Delta q} / \mathbf{\Delta p}$ & $\begin{array}{c}\text { Ka } \\
(\mathbf{M P a})\end{array}$ & $\begin{array}{c}\mathbf{G a} \\
(\mathbf{M P a})\end{array}$ & $\mathbf{n}$ & $\boldsymbol{\gamma}$ & Correlation \\
\hline $\mathrm{A}$ & 3 & 6.24 & 19.02 & 0.30 & 0.28 & 0.590 \\
\hline B & $\begin{array}{c}0,0.5, \\
1,1.5 \\
\text { and 2 }\end{array}$ & 31.05 & 47.98 & 0.48 & 0.59 & 0.898 \\
\hline
\end{tabular}

Hornych et. al [27] used Boyce Model to describe the resilient behaviour of UGM and Gravel Emulsion (GE), with stress ratios $\Delta \mathrm{q} / \Delta \mathrm{p}$ varying between 0 and 2 . They founded an anisotropy coefficient close to 1 for UGM and 0.8 for GE. Consequently, the fit B allows a modelling more representative mechanical behaviour. 
Indeed, the equation (14) explains the link between $\gamma$, vertical modulus $\mathrm{E}_{\mathrm{v}}$ and horizontal modulus $\mathrm{E}_{\mathrm{h}}$. For the fit $\mathrm{A}, \mathrm{E}_{\mathrm{v}} / \mathrm{E}_{\mathrm{h}}$ is a very large value close to 13 , whereas for fit $\mathrm{B}$ the ratio is equal to 2.9. Consequently, the stress paths of slope 3 have to be associated to the other slopes to describe the resilient behaviour.

$$
E_{v} / E_{h}=1 / \gamma^{2}
$$

In order to propose one set of parameters, a calibration with all stress paths was performed. The parameters and the correlation value are detailed in table 7 . The parameters of this last correlation are quite close of fit B.

Table 7. One set of Mohr-Coulomb parameters.

\begin{tabular}{|c|c|c|c|c|c|}
\hline$\Delta \mathbf{q} / \mathbf{\Delta p}$ & $\begin{array}{c}\text { Ka } \\
\text { (MPa) }\end{array}$ & $\begin{array}{c}\text { Ga } \\
\text { (MPa) }\end{array}$ & $\mathbf{n}$ & $\boldsymbol{\gamma}$ & Correlation \\
\hline $\begin{array}{c}\text { From } \\
0 \text { to 3 }\end{array}$ & 30.42 & 53.30 & 0.46 & 0.59 & 0.891 \\
\hline
\end{tabular}

\section{Conclusion}

This paper presents some elements about a source of reclaimed asphalt aggregates with high $\mathrm{PAH}$ content. The aim of this research is to develop a strategy of cold recycling without binder addition.

The monotonic triaxial tests at three temperatures and at fixed density demonstrate some points:

- AA are sensitive to temperature.

- At $50^{\circ} \mathrm{C}$, the resistance to failure is lower than at $20^{\circ} \mathrm{C}$. - Preheating the sample allows to increase the cohesion. - Performing the steps of mixing and compaction at $50^{\circ} \mathrm{C}$ could provide an increase of density and consequently improved mechanical performances.

The RLT tests at ambient temperature allowed to measure the permanent and resilient strains and to observe the behaviour of AA subjected to different levels of stress paths. The results reveal a stress dependent resilient behaviour.

Regarding the modelling, the non-linear elastic Boyce model is able to estimate the resilient behaviour at ambient temperature.

To complete this research, additional RLT tests at different temperatures will allow to study the impact of this parameter. Then, the next objective is to reduce the rutting by means of a higher density of AA.

This work is part of a European project: ORRAP (Optimal Recycling of Reclaimed Asphalts in low-traffic Pavements). ERDF - INTERREG V funds this research.

\section{References}

1. G. Valdés, F. Pérez-Jiménez, R. Miró., A. Martínez, R. Botella, Constr. Build Mater. 25(3), 1289-1297 (2010)

2. B. Colbert, Z. You, Constr. Build Mater. 26(1), 655662 (2011)
3. B. Kalman, Project Final Report (Re-Road - End of Life Strategies of Asphalt Pavements) http://reroad.fehrl.org/ (2013)

4. N. Tran, R. West, A. Taylor, R. Willis, Int. J. Pavement Eng. 18(9), 851-858 (2015)

5. K.H. Moon, A. Cannone Falchetto, D. Wang, M.P. Wistuba, G. Tebaldi, Road Mater. Pavement 18(2), 297-314 (2016)

6. D. Singh, S.F. Chitragar, P.K. Ashish, Constr. Build Mater. 157, 1145-1153 (2017)

7. C. Plati, A. Loizos, V. Papavasiliou, A. Kaltsounis, Adv.Civil.Eng. 10(ID 565924) (2010)

8. F.V. Guatimosim, K.L. Vasconcelos, L.L.B. Bernucci, K.J. Jenkins, Road Mater. Pavement 19(2), 385-399 (2016)

9. K. Kuna, G. Airey, N. Thom, Int. J. Pavement Eng. 18(10), 902-915 (2016)

10. T. Jacobson, Cold recycling of asphalt pavementmix in plant (Road Pavement Recycling, Warsaw, 2002)

11. M. Dinis-Almeida, J. Castro-Gomes, M. de Lurdes Antunes, Constr. Build Mater. 28(1), 687-693 (2011)

12. C. Sangiorgi, P. Tataranni, A. Simone, V. Vignali, C. Lantieri, G. Dondi, Constr. Build Mater. 138, 232239 (2017)

13. AFN, Graves non traitées: Spécifications NF EN 13285, 6-7 (2004)

14. AFN, Mélanges bitumineux: Spécifications des matériaux - Partie 1: Enrobés bitumineux NF EN 13108-1, 9-11 (2007)

15. AFN, Sols : Reconnaissance et essais - Identification granulométrique - Méthode de tamisage par voie humide XP P 94-041 (1195)

16. AFN, Sols: Reconnaissance et essais Détermination des références de compactage d'un matériau - Essai Proctor normal - Essai Proctor modifié NF P 94-093 (1999)

17. AFN, Mélanges bitumineux : Méthodes d'essai pour mélange hydrocarboné à chaud-Partie 1: Teneur en liant soluble NF EN 12697-1 (2012)

18. AFN, Bitumes et liants bitumineux: Détermination de la pénétrabilité à l'aiguille NF EN 1426 (2007)

19. AFN, Bitumes et liants bitumineux : Détermination $d u$ point de ramollissement - Méthode Billet et Anneau NF EN 1427 (2007)

20. T. Gabet, M. Wayman, Sampling procedure for reclaimed asphalt (Re-Road - End of Life Strategies of Asphalt Pavements) http://re-road.fehrl.org/ (2012)

21. P. Jing, H. Nowamooz, C. Chazallon, Road Mater. Pavement 19(2), 298-314 (2016)

22. X.N. Ho, H. Nowamooz, C. Chazallon, B. Migault, Road Mater. Pavement 16(9), 842-856 (2014)

23. AFN, Mélanges traités et mélanges non traités aux liants hydrauliques - Partie 4: Méthodes d'essai pour la masse volumique de référence et la teneur en 
eau en laboratoire - Marteau vibrant NF EN 132864 (2003)

24. AFN, Mélanges avec ou sans liant hydraulique Partie 7 : Essai triaxial sous charge cyclique pour mélanges sans liant hydraulique NF EN 13286-7 (2004)

25. J.R Boyce, A non-linear model for the elastic behaviour of granular materials under repeated loading (International Symposium on Soils under Cyclic and Transient Loading, Swansea, 1980).

26. P. Hornych, A. Kazai, J.M. Piau, Study of the resilient behaviour of unbound granular materials (Fifth International Conference on the Bearing Capacity of Roads and Airfield, Trondheim, Norway, 1998)

27. P. Hornych, V. Gaudefroy, J.L. Geffard, S. Goyer, Study of the mechanical behaviour of gravelemulsions using triaxial tests (Seventh International Symposium on Advanced Testing and Characterization of Bituminous Materials, Rhodes, Greece, 2009) 